\title{
COMMUNICATION
}

\section{Bovine Prothrombin Does not Contain $\alpha$-D-Galactopyranosyl Groups}

\author{
A. E. ECKHARD'T ${ }^{*}$ I. J. GOLDSTEIN* AND G. L. NELSESTUEN† \\ * Department of Biological Chemistry, University of Michigan, Ann Arbor, Michigan 48109, and \\ + Department of Biochemistry, University of Minnesota, St. Paul, Minnesota 55101
}

Received October 2, 1979

Lsing purified lectins (Bandeiraea simplicifolia $\mathrm{I}_{-} \mathrm{B}_{4}$ isolectin and the castor bean agglutinin) and glycosidases ( $\alpha$ - and $\beta$-galactosidases) we have shown that the terminal, nonreducing galactopyranosyl groups of asialoprothrombin possess the $\beta$-configuration rather than the $\alpha$-anomeric form previously reported.

In 1972 Nelsest uen and Sut tie report erl the presence of $\alpha$-I)-galactopyranosyl units in bovine prothrombin (1). The rare occurrence of this sugar group in animal glycoproteins prompted us to reexamine this point. Using a combination of specific cleavage with purified glycosidases and reactivity with lectins of known specificity we now report that the glycosyl moiety of bovine asialoprothrombin terminates in $\beta$-D-galactosyl units rather than $\alpha$-D-galactosyl groups.

\section{MATERIALS AND METHODS}

Bovine prothrombin was prepared by a modification (2) of the procedure of Ingwall and Scheraga (3) and desialylated with neuraminidase as described by Nelsestuen and Suttie (4). Bovine testis $\beta$-galactosidase was a gift of Dr. G. W. Jordian of this University. Coffee bean $\alpha$-galactosidase and galactose dehydrogenase were purchased from Boehringer-Mannheim. Ficin $\alpha$-galactosidase was a gift of Dr. Y. T. Li of Tulane Lniversity. Both $\alpha$-galactosidases failed to hydrolyze $p$-nitrophenyl $\beta$-D galactopyranoside. Bandeiraea simplicifolia $\mathrm{I}_{-} \mathrm{B}_{4}$ isolectin was prepared according to Murphy and Goldstein (5) and coupled to Sepharose 4B by the procerlure of Rosset al. (6). Bardeiraea simplicifolia II lectin was prepared by the procedure of Shankar Iyer et al. (7). The castor bean agglutinin $\left(\mathrm{RCA}_{1}\right)$ was a gift of Dr. Marilyn Etzler, University of California at Davis.

The digestion of asialoprothrombin, $5.3 \mathrm{mg} / \mathrm{ml}$, with coffee bean $\alpha$-galactosidase or bovine testis $\beta$-galactosidase was conducted at $37^{\circ} \mathrm{C}$ in $0.05 \mathrm{~m}$ citrate buffer, pH 6.0, containing $0.04 \% \mathrm{NaN}_{3}$. The digestion with ficin $x$-galactosiclase was performed using the sante buffer but at $\mathrm{pH}$ 5.0. The final glycosidase concentrations were 0.1 unit/ml for ficin $\alpha$-galactosidase and coffee bean $\alpha$-galactosidase and 0.27 unit/mul for bovine test is $\beta$-galactosidase. Aliquots were removed at various time intervals and assayed for D-galactose using galactose dehydrogenase. Protein determinations were carried out by the method of Iowry ef al. (8) with bovine serum albumin as standard.

\section{RESULTS AND DISCUSSION}

Bovine asialoprothrombin failed to form a precipitate with the $B$. simplicifolia $\mathrm{I}_{-} \mathrm{B}_{4}$ isolectin or to bind to the same lectin immobilized on Sepharose $4 B$. On the other hand, the glycoprotein did precipitate with $\mathrm{RCA}_{\mathrm{I}}$, the castor bean agglutinin. This lectin does not distinguish between $\alpha$-or $\beta$-D-galactosyl end groups (9).

$\alpha$-Galactosidase from coffee bean or ficin failed to liberate D-galactose from bovine asialoprothrombin after $192 \mathrm{~h}$ incubation (Fig. 1). On the other hand, bovine testis $\beta$-galactosidase released $6 \mathrm{~mol}$ of $\mathrm{D}$-galactose/mol glycoprotein. (Fig. 1). This enzyme contained no detectable $\alpha$-D-galactosirlase activity as determined by failure to hydrolyze $p$-nitrophenyl $\alpha$-D-galactopyranoside. Following release of D-galactose by the $\beta$-galactosiclase, the resulting glycoprotein reacted vigorously with $B$. simplicifolia II lectin, an agglutinin specific for $N$ acetyl-D glucosamine end groups (7).

These results demonstrate the presence of six terminal, nonreducing $\beta$-D-galactopyranosyl units which mask 2-acetamido-2-deoxy-D-glucopyranosyl residues. It would appear that the $\alpha$-galactosidase used by the earlier workers contained small amounts of contaminating $\beta$-galactosidase which, during the long incubation period $(250 \mathrm{~h}$ ), released D-galactose, the latter being attributed to the presence of $\alpha$-D-galactosyl end groups. Thus far, $\alpha$-D-galactopyranosyl units have been reported only in the following glycoproteins: blood group B substance (10), earthworm cuticle collagen (11), bonnel monkey cervical mucin (12), rat brain glycopeptide (13), and most recently in membrane glycoprotein of Ehrlich ascites tumor cells (14) and basement membrane components of the mouse, rat, rabbit, and bovine species (15).

While this manuscript was in preparation, Kabota and his colleagues (16) also reported on their failure 


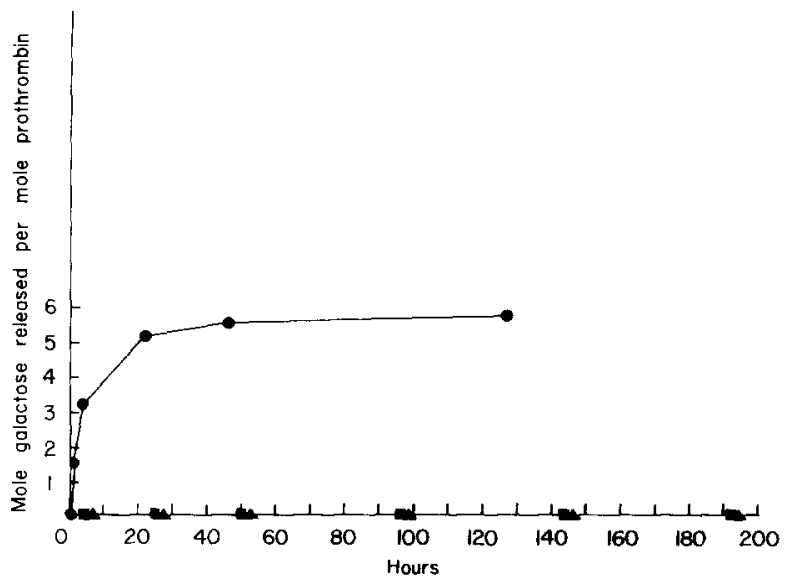

FIG. 1. Action of $\alpha$-and $\beta$-galactosidases on asialoprothrombin. ( $)$ Bovine testis $\beta$-galactosidase; ficin $\alpha$-galactosidase; ( $\boldsymbol{\Lambda}$ ) coffee bean $\alpha$-galactosidase.

to confirm the presence of $\alpha$-D-galactosyl groups in bovine prothrombin.

\section{ACKNOWLEDGMENTS}

This research was supported by Public Health Service Grants AM-10171 and CA-26424 from the National Institutes of Health.

\section{REFERENCES}

1. Nfirsestuen, G. I.., ann Suttif., J. W. (1972) J. Biol. Chem. 247, 6096-6102.

2. Nelisestuen, G. L., AND Sut'ite, J. W. (1973) Proc. Nat. Acad. Sci. USA 70, 3366-3370.

3. INGWALl, J. S., AND ScheraGA, H. A. (1969) Biochemistry 8, 1860-1869.

4. Nelsestuen, G. L., AND SutTie, J. W. (1971) Biochem. Biophys, Res. Commun. 45, 198-203.

5. MuRPhy, L. A., AND Goldstein, I. J. (1977) J. Biol. Chem. 252, 47394742.

6. Ross, T. T., Hayes, C. E., and Goldstein, I. J. (1976) Carbohyd. Res. 47, 91-97.
7. SHANKAR IYer, P. N., WILKINSON, K. D., AND Goldstein, I. J. (1976) Arch. Biochem. Biophys. 177, 330-333.

8. Lowry, O. H., Rosebrough, N. J., Farr, A. L., AND RANDALL, R. J. (1951) J. Biol. Chem. 193, 265-275.

9. Nicolson, G. L., Blaustein, J., ANd Etzler, E. (1974) Biochemistry 13, 196-204.

10. KabAT, E. A. (1956) Blood Group Substances, p. 1, Academic Press, New York.

11. Muir, L., And LeE, Y. C. (1969) J. Biol. Chem. $244,2343-2349$.

12. Hatcher, V. B., Schwartz Mann, G. O. H., JEANLOZ, R. W., AND MCARTHUR, J. W. (1977) Biochemistry 16, 1518-1524.

13. Finne, J., AND Krusius, T. (1976) FEBS Lett. 66, 94-97.

14. Eckhardt, A. E., ANd Goldstein, I. J. (1979) Glycoconjugate Res. 2, 1043-1045.

15. Peters, B. P., And Goldstein, I. J. (1979) Exp. Cell. Res. 120, 321-334.

16. Mizuochi, T., Yamashita, K., Fujikawa, K. Kisiel, W., and Kobata, A. (1979) J. Biol. Chem. 254, 6419-6425. 